\title{
Electronic Visualisation and the Arts (EVA 2009)
}

\author{
London, UK \\ 6 - 8 July 2009
}

Editors:

Alan Seal

Suzanne Keene

Professor Jonathan P. Bowen 


\section{Abstract}

Electronic Visualisation and the Arts London 2009 (EVA 2009) is co-sponsored by the Computer Arts Society and the British Computer Society, of which the Computer Arts Society is a specialist group. Since 1992, the EVA conference series has established itself as a natural home from which to explore the richly interdisciplinary and constantly evolving world of digital visualisation. Nothing illustrates this more than the great scope, depth and diversity of the papers contained within this year's Proceedings.

The latest research in digital arts and new media are explored, with contributors ranging from established scholars to the new generation of research students who will lead the field tomorrow. Conference papers cover reconstructive archaeology, virtual museology, digital arts concepts and practice, immersive environments, and digital performance and music. 


\section{Full Synopsis}

EVA 2009 brought together a range of digital imaging, museum and visual arts practitioners from across the world. This demonstrates the diversity of interests within the field of digital visualisation, as did the range of contributors from graduate artists and $\mathrm{PhD}$ students to seasoned industry professionals who value EVA for this reason.

The conference included three keynote speakers: Kim Veltman, world authority on information organisation and visual culture; Professor Ernest Edmonds, organiser of Creativity and Cognition and editor of Leonardo Transactions; and digital artist Gordana Novakovic, currently artist in residence at the Department of Computer Science, UCL. They spoke about the growing impact of digital visualisation in different aspects of contemporary culture and the need for it to be extended by strong high-level research, and not relegated to the status of mere 'visuals'. A common theme was that visualisation can not only help science become more explicable, but can in fact draw out information that was previously concealed in data by rendering it visible in new ways. This was also alluded to by our chairman George Mallen in his summing up on the final afternoon, when he called for more support for this activity.

Specific themes included Archaeology, Digital History and Virtual Museology; Digital Art Theory and Practice; and Interfaces, Digital Performance and Digital Music. This structure helped to highlight the diverse interests of EVA members and allowed a range of new projects to be studied in relation to other aspects of the field. With contributions from researchers in university departments, museums and the private sector, as well as artists and independent developers, the breadth of concerns in digital visualisations was well-represented. Projects ranged from 3D scanning of prehistoric rock art to new techniques of rapid prototyping being used by printmakers at the Royal College of Art.

As with last year, the demonstrations and parallel Research Workshops enabled a variety of systems and interfaces to be experienced firsthand. This side of EVA is as important as its published transactions because it embodies the very interdisciplinarity that EVA seeks to encourage, drawing together the visual and computational fields.

EVA 2009 marks the second year of our very successful partnership with the BCS. All attendees remarked on the suitability of the venue and appreciated having a printed volume of papers accompanying their registration. We would like to extend our thanks to the BCS for their customary smooth and efficient organisation, and in particular to Gemma Liddiard for supporting us before and during the conference. We look forward to future collaborations with the BCS. 


\section{Editors}

Alan Seal has recently worked as Head of Records and Collections Services in the Victoria and Albert Museum where he was responsible for the photographic services and archive in the museum and the automation and digitisation of the collections. He was previously Head of Collections Management in the National Art Library in the V\&A. A librarian by training, he is particularly interested in user interfaces and online public access systems, both textual and multi-media. He has undertaken research into bibliographic standards in information systems and online library catalogues during a period at the Centre for Catalogue Research at the University of Bath.

Suzanne Keene's background is in large-scale collection management in museums, including digital technologies. At University College London, she directed the MA in Museum Studies. She has recently completed a large research project investigating the uses of museums' stored collections.

www.ucl.ac.uk/storedcollections

Professor Jonathan P. Bowen, FBCS FRSA, is a computer scientist and Chair of Museophile Limited, a museum and IT consultancy company. He is also a Visiting Professor at King's College London and an Emeritus Professor at London South Bank University www.jpbowen.com 


\section{Papers:}

\section{Session 1: Reconstructive Archaeology}

Paul Bryan Recording Prehistoric Rock-art: A Three Dimensional Approach

http://dx.doi.org/10.14236/ewic/EVA2009.1

Hugh Corley Tagged: Digital Photography and Archaeologists

http://dx.doi.org/10.14236/ewic/EVA2009.2

Graeme Earl, Gareth Beale, Jassim Happa, Mark Williams, Glen Turley, Kirk Martinez and Alan Chalmers A Re-Painted Amazon http://dx.doi.org/10.14236/ewic/EVA2009.3

\section{Session 2: Digital History}

Martyn Jessop The Domesday Book: Visualization Tools to Explore Identity at the start of the Second Millennium http://dx.doi.org/10.14236/ewic/EVA2009.4

Nic Earle and Shelley Hales Pompeii in the Crystal Palace: Comparing Victorian and Modern Virtual, Immersive Environments http://dx.doi.org/10.14236/ewic/EVA2009.5

Oana Gui, Ioan Petrescu, Theo Muresan, Oana Mara Gui, Radu Solovastru, Paul Valentin Borza and Dan Dumitrescu Considerations Regarding the use of the Biologically Inspired Retinex Algorithm in Art Conservation-Restoration http://dx.doi.org/10.14236/ewic/EVA2009.6

\section{Session 3: Digital History}

Mathias Fuchs Digital Tudor http://dx.doi.org/10.14236/ewic/EVA2009.7

Crandall Shifflett Virginia Chesapeake

Jane Devine Mejia Learning in Design
Paspahegh: Visualizing a Seventeenth-Century Algonquian Indian Village in the http://dx.doi.org/10.14236/ewic/EVA2009.8

Online Exhibitions and Archives: A Collaborative Project for Teaching and http://dx.doi.org/10.14236/ewic/EVA2009.9 


\section{Session 4: Virtual Museology}

James Coltrain A Picture is Worth 1,000 Pasts: How 3D Virtual Reconstructions Can Bridge the Gap Between Visitor Interest and Scholarly Debate http://dx.doi.org/10.14236/ewic/EVA2009.10

Angelina Russo Our Space: The Convergance of Cultural Interactive Experiences and Distributed Innovation in Museums http://dx.doi.org/10.14236/ewic/EVA2009.11

Francesca Monti The Tomb-Chapel of Nebamun at the British Museum: The Digital, the Spectacular, and the Inconspicuous Under One Limestone Roof

http://dx.doi.org/10.14236/ewic/EVA2009.12

\section{Session 5: Digital Arts: History and Theory}

Ernest Edmonds New constructs in Art: Structure, Time, Correspondences and Interaction http://dx.doi.org/10.14236/ewic/EVA2009.13

Catherine Mason The Fortieth Anniversary of Event One at the Royal College of Art http://dx.doi.org/10.14236/ewic/EVA2009.14

Stefan Zedlacher and Michael Stadler Mediated Situationism http://dx.doi.org/10.14236/ewic/EVA2009.15

\section{Session 6: Digital Arts: Practice}

Jeremy Gardiner Light Years: Jurassic Coast an Immersive 3D Landscape Project http://dx.doi.org/10.14236/ewic/EVA2009.16

Frank Watson and Dave Lawrence Isles of Grain http://dx.doi.org/10.14236/ewic/EVA2009.17

Jeehee Lee The Secret Garden http://dx.doi.org/10.14236/ewic/EVA2009.18

Session 7: Digital Arts: Concepts 
Gordana Novakovic Fugue and Variations on some Themes in Art and Science http://dx.doi.org/10.14236/ewic/EVA2009.19

Lijia Ke Relating Tradition to Innovation within Chinese Art http://dx.doi.org/10.14236/ewic/EVA2009.20

\section{Session 8: Digital Arts: Practice}

Sophy Smith The Creative Uses of Facebook as a Tool for Artistic Collaboration http://dx.doi.org/10.14236/ewic/EVA2009.21

Anastasios Maragiannis Visual Arts and 2D - 3D Motion Typo.graphic Design http://dx.doi.org/10.14236/ewic/EVA2009.22

Violetta Dajanev Open Access to Digital Culture for Non-Professional Creatives http://dx.doi.org/10.14236/ewic/EVA2009.23

\section{Session 9: Interfaces and Tracking}

Gordana Novakovic The Interface behind the Face http://dx.doi.org/10.14236/ewic/EVA2009.24

Myrto Karanika Strings: A Haptic Interface $\quad$ http://dx.doi.org/10.14236/ewic/EVA2009.25

Mariza Dima, John Lee, Mark Wright, Abi Ullattil and Xiaoqing Cao Designing a Haptically Extended Interface for Digitally Animating 3D Articulated Characters

http://dx.doi.org/10.14236/ewic/EVA2009.26

Amir Soltani Panohaptic Interface for Architectural Filmic Improvisation

http://dx.doi.org/10.14236/ewic/EVA2009.27

\section{Session 10: Digital Performance}

Carl Smith The Unit of Construction + the Multiple Point of View $=$ the Evolution of Form http://dx.doi.org/10.14236/ewic/EVA2009.28 


\section{Session 11: Immersive Environments}

Thomas Duncan and Noel McCauley Narrative Space Architecture and Digital Media http://dx.doi.org/10.14236/ewic/EVA2009.29

Colin B. Price, June S. Moore and Joanne M. Kuzma Deconstruction-reconstruction of Computer Game and Immersive Environment Semiotics http://dx.doi.org/10.14236/ewic/EVA2009.30

Joanne Tompkins and Matt Delbridge Using Virtual Reality Modelling in Cultural Management, Archiving and Research $\quad$ http://dx.doi.org/10.14236/ewic/EVA2009.31

\section{Session 12: Computers, Music and Things}

Mick Grierson Plundermatics: Real-time Interactive Media Segmentation for Audiovisual Analysis, Composition and Performance http://dx.doi.org/10.14236/ewic/EVA2009.32

Tom Keene and Kypros Kyprianou $\quad$ Aristotle's Officehttp://dx.doi.org/10.14236/ewic/EVA2009.33 